\title{
Market Share Thresholds: On the Conflation of Empirical Assessments and Legal Policy Judgments
}

\section{Citation}

Louis Kaplow, Market Share Thresholds: On the Conflation of Empirical Assessments and Legal Policy Judgments, 7 J. Competition L. \& Econ. 243 (2011).

\section{Published Version}

http://jcle.oxfordjournals.org/content/7/2/243.full.pdf+html

\section{Permanent link}

http://nrs.harvard.edu/urn-3:HUL.InstRepos:30012782

\section{Terms of Use}

This article was downloaded from Harvard University's DASH repository, and is made available under the terms and conditions applicable to Open Access Policy Articles, as set forth at http:// nrs.harvard.edu/urn-3:HUL.InstRepos:dash.current.terms-of-use\#OAP

\section{Share Your Story}

The Harvard community has made this article openly available. Please share how this access benefits you. Submit a story.

Accessibility 


\title{
HARVARD
}

JOHN M. OLIN CENTER FOR LAW, ECONOMICS, AND BUSINESS

\author{
MARKET SHARE THRESHOLDS: \\ ON THE CONFLATION OF \\ EMPIRICAL ASSESSMENTS AND \\ LEGAL POLICY JUDGMENTS
}

\author{
Louis Kaplow
}

Discussion Paper No. 692

$05 / 2011$

Harvard Law School

Cambridge, MA 02138

This paper can be downloaded without charge from:

The Harvard John M. Olin Discussion Paper Series: http://www.law.harvard.edu/programs/olin_center/

The Social Science Research Network Electronic Paper Collection:

http://ssrn.com/ 
JEL codes: D42, K21, L40

\title{
Market Share Thresholds: On the Conflation of Empirical Assessments and Legal Policy Judgments
}

\author{
Louis Kaplow*
}

\begin{abstract}
In competition law, market power requirements are often articulated in terms of market shares. The use of market share thresholds, however, conflates two distinct questions: (1) How much market power exists in a given situation? (2) How much market power should the law require? As a consequence, neither question is answered, or even directly illuminated. Furthermore, because market shares are not themselves measures of market power but instead merely a factor that bears on its magnitude in a given setting, they are inapt answers to both inquiries. Their use involves a category mistake. The identified problems are illustrated by unpacking Learned Hand's famous pronouncement in Alcoa of the market shares required for the offense of monopolization, but the core defects characterize all market share declarations.
\end{abstract}

Forthcoming, Journal of Competition Law and Economics, vol. 7 (2011)

*Harvard Law School and National Bureau of Economic Research. I am grateful to Harvard Law School's John M. Olin Center for Law, Economics, and Business for financial support. This article (especially part V) has its origins in my teaching the Alcoa case since the 1980s, revision of the text and questions and preparation of the teachers' manual on market power and market definition for Antitrust Analysis (with Phillip Areeda) in 1988, and an unpublished lecture presented to National Association of Attorneys General antitrust lawyers in 1990. Some elements are suggested in the 2007 Handbook of Law and Economics antitrust chapter (with Carl Shapiro). I have benefited from prior interchanges with my co-authors. 


\title{
Market Share Thresholds: On the Conflation of Empirical Assessments and Legal Policy Judgments
}

\author{
Louis Kaplow \\ (C) 2011. All Rights Reserved.
}

\section{TABLE OF CONTENTS}

I. Introduction

II. Market Power and Market Share Threshold Tests
A. Market Power
B. Market Share Threshold Tests

III. Two Distinct Questions; No Market Share Answers
A. Empirical Assessment
B. Legal Policy Judgment

IV. Standard Reference Market as a Clarifying Construct
A. Construction
B. Implications

V. Demonstrating Conflation: Unpacking Alcoa

VI. Reflections on Official (Non)Pronouncements of Market Power Requirements

VII. Conclusion 


\section{INTRODUCTION}

Perhaps the most well-known pronouncement of a market share threshold is Learned Hand's decree in Alcoa that ninety percent "is enough to constitute a monopoly; it is doubtful whether sixty or sixty-four percent would be enough; and certainly thirty-three per cent is not." But what does this famous announcement mean? Is this a statement about how much market power the court thought was associated with the corresponding market shares? (In the aluminum industry under consideration, or more generally?) Or is this a statement about how much market power is required for the offense of monopolization?

For the opinion to make sense, the declaration has to answer both questions. Yet how can a single proclamation answer two separate, qualitatively different questions simultaneously? The simple answer is that it cannot. Even worse, by conflating the distinct questions, it turns out that the announcement cannot provide a coherent answer to either one.

There is another important reason why Hand's famous utterance answers neither of our two questions, one about the empirical assessment of market power in a given case and the other about the legal policy judgment of how much market power should be required: Market shares do not constitute answers to questions about market power. To assume otherwise involves a category mistake, just as would be the case if a uniform speed limit was articulated by the number of RPMs of vehicles' engines. The two are related, but each measures a different type of phenomenon. (Unlike Fahrenheit-Celsius conversion but like market power and market share, there is no perfect translation but rather a positive, noisy correlation; the same RPMs indicate different speeds for different engine types, vehicle weights, and road conditions.)

This problem, moreover, is not limited to Alcoa's announcement. These fatal defects are fully applicable to other market share thresholds advanced by courts, competition authorities, and commentators. This predicament has a paradoxical feature. On one hand, everyone knows the difference between the empirical question of extant market power and the policy question of requisite market power. On the other hand, most statements - whether by adjudicators, agencies, or analysts - on the subject (and, worse, most thinking as well) conflate these distinct matters and attempt to address them in terms that make little sense. A wholesale change in approach is therefore required.

Part II begins the inquiry by defining market power and noting the existence of numerous market power requirements under competition law. It is emphasized that, although the problem of how to assess market power is an important one, it is independent of the present inquiry. This

\footnotetext{
${ }^{1}$ United States v. Aluminum Co. of America, 148 F.2d 416, 424 (2d Cir. 1945). The unusual weight given to this circuit court opinion is due in part to Hand's stature (and that of his fellow panelists) and to the fact that the Second Circuit Court of Appeals heard the case in lieu of the Supreme Court because four justices disqualified themselves, thereby depriving the Court of a quorum. On the prominence of this passage, see, for example, Spencer W. Waller, The Story of Alcoa: The Enduring Questions of Market Power, Conduct, and Remedy in Monopolization Cases, in AnTITRUst Stories 121, 142 (Eleanor M. Fox \& Daniel A. Crane eds., 2007) ("However, much of Alcoa remains good law or the subject for contemporary debate. Hand's rule of thumb, that a $90 \%$ market share is probably a monopoly, $60 \%$ is doubtful, and $33 \%$ cannot be, is one of the most quoted aphorisms in antitrust law.").
} 
part also notes how legal market power rules are commonly formulated as market share threshold tests.

Part III elaborates on each of the two market power questions, involving empirical assessments and legal policy judgments. Although the distinction is understood, some further analysis of each helps sharpen the differences. Furthermore, clarification of these questions makes it obvious that neither question can be answered in market share terms, as is commonly done with regard to both. Since market shares are not even in like-kind units with market power (i.e., the problem is not merely one of language translation or conversion of units of measure), the challenge is not merely pragmatic but conceptual. If, however, it so happened that there was some iron relationship between market power and market share — or even a reasonably tight correlation - the problem may not be that important in practice. But for decades, if not longer, no serious analyst or competition law authority has believed this to be true. ${ }^{2}$

Part IV examines whether there is any way to rescue market share thresholds. It presents the notion of a standard reference market, which is a hypothetical construction designed to provide a common benchmark (a sort of translation table) for linking market power measures and market shares. On one hand, this construct works in that it enables intelligible communication. On the other hand, to accomplish this feat it is necessary to abandon any meaningful sense in which market share threshold tests refer to real market shares in actual markets.

Part V returns to the Alcoa quotation and uses it to demonstrate more systematically the manner in which market share thresholds conflate the two questions of the extent of market power and the legally required degree of market power. Having in prior parts highlighted the nature of each question and provided a method for relating market power and market shares, it becomes straightforward to see the inherent limitations not only of Hand's statement but of all attempts to formulate legal market power requirements in market share terms.

Part VI notes that, not only have market power rules been stated using market shares, but authorities and commentators virtually never offer rules or analyses that are directly in terms of market power, which is necessary to formulate sensible competition policy. Conjectures are offered regarding why this state of affairs exists. It is suggested that market share tests and their resulting conflation with market power assessments in particular cases are appealing due to the apparent but deceptive simplicity of the approach. Relatedly, the attraction has a symbiotic relationship with adherence to the market definition / market share paradigm for measuring market power (which itself is highly problematic, a matter not considered here ${ }^{3}$ ). That is, stating market power requirements as market share threshold tests encourages use of the market definition / market share paradigm (because it has a market share as its direct output), and using the paradigm likewise encourages the statement of legal rules in market share terms.

\footnotetext{
${ }^{2}$ Note that, under some approaches, market share is relevant to the empirical assessment of market power as one factor, just as there are valid approaches to determining a vehicle's speed that use RPMs as one input to the analysis. Even then, it would be an error to treat RPMs as if synonymous with speed.

${ }^{3}$ The subject is taken up in Louis Kaplow, Why (Ever) Define Markets?, 124 HARV. L. REV. 437 (2010).
} 
Part VII concludes by advocating that all empirical market power assessments and legal market power tests be denominated in market power terms. Both tasks are demanding. No matter how difficult they prove to be, however, competition law cannot hope to do better by continuing to conflate these two distinct questions and adhere to an approach that provides logically and practically nonresponsive answers to both of them.

\section{MARKET POWER AND MARKET SHARE THRESHOLD TESTS}

Section A defines market power, mentions the more prominent market power requirements in competition law, and comments briefly on the determination of market power. Section B notes that many market power requirements are implemented using market share threshold tests.

\section{A. Market Power}

The most common and probably most workable definition of market power is the ability to profitably elevate price $(P)$ above the competitive level, which in the case of perfect competition would be a price equal to firms' marginal costs $(M C)$, which would be equated through the competitive process. The extent of market power is accordingly the degree to which the profit-maximizing price exceeds the competitive level. ${ }^{4}$ (This definition of market power is

\footnotetext{
${ }^{4} S e e$, e.g., U.S. DeP’ T OF Justice \& Fed. Trade Comm’n, Horizontal Merger Guidelines $§ 1$ (2010) [hereinafter U.S. MERGER GUIDELINES] (“A merger enhances market power if it is likely to encourage one or more firms to raise price, reduce output, diminish innovation, or otherwise harm customers as a result of diminished competitive constraints or incentives. . . . For simplicity of exposition, these Guidelines generally discuss the analysis in terms of . . . price effects."); 2B PHILlip E. AREEDA, HERBERT HovenKAMP, \& JOHN L. SOlOW, ANTITRUST LAW: AN ANALYSIS OF ANTITRUST PRINCIPLES AND THEIR APPLICATION 109 (3rd ed. 2007) ("Market power is the ability to raise price profitably by restricting output.”); VALENTINE KORAH, AN INTRODUCTORY GUIDE TO EC COMPETITION LAW AND PRACTICE 119 (9th ed. 2007) ("In Continental Can, the ECJ implicitly accepted the Commission's definition of dominant position based on the economists' concept of power over price . . ..”); Dennis W. Carlton, Market Definition: Use and Abuse, 3 COMPETITION POL'Y INT'L 3, 5 (2007) (“One standard definition of market power is the ability to set price profitably above the competitive level, which is usually taken to mean marginal cost.”); William M. Landes \& Richard A. Posner, Market Power in Antitrust Cases, 94 HARV. L. REV. 937, 937 (1981) ("The term 'market power' refers to the ability of a firm (or a group of firms, acting jointly) to raise price above the competitive level without losing so many sales so rapidly that the price increase is unprofitable and must be rescinded."); $i d$. at 939 ("A simple economic meaning of the term 'market power' is the ability to set price above marginal cost."); Gregory J. Werden, Demand Elasticities in Antitrust Analysis, 66 AnTITRUST L.J. 363, 373-74 (1998) (tracing the U.S. Supreme Court's acceptance of this economic definition of market power beginning in the 1960s, and further stating that "The courts of appeals have widely used the economic definition of market power."). A commonly cited definition is that "Monopoly power is the power to control prices or exclude competition.” United States v. E.I. du Pont de Nemours \& Co, 351 U.S. 377, 391 (1956) (Cellophane). Two differences may be noted briefly. Most obviously, this formulation adds the alternative of being able to exclude competition. Some have rationalized this phrasing as indicating that a monopolist (the focus of inquiry in Cellophane) might use its power either to raise price or instead, perhaps in a predatory manner, to exclude competition. Others have interpreted "or" as "and," emphasizing that the ability to raise prices over a significant period of time requires somehow keeping competitors at bay. See, e.g., Richard Schmalensee, Another Look at Market Power, 95 HARV. L. REV. 1789, 1795 (1982) (rationalizing the Cellophane language as distinguishing the short- and long-run exercises of market power). The other, more subtle difference - echoed more sharply in some other versions as well - is the reference to the ability to "control" price; others have referred to a firm having discretion or, in the words of Michelin v. Commission, Case 322/81 [1983] ECR $3461 \S 30$, in the European Union, "to behave to an appreciable extent independently of its competitors and customers." Most of these alternatives are vague and potentially misleading. A firm with little market power can still
} 
chosen for concreteness and because of its familiarity and wide endorsement. The analysis throughout this article would be largely the same if a different notion were employed. ${ }^{5}$ )

This concept of market power is often expressed using the Lerner index, $L=(P-M C) / P$, also known as the price-cost margin. ${ }^{6}$ The Lerner index indicates the portion of the price that is in excess of what is required to cover marginal cost. For example, if $P=100$ and $M C=80$, then $L=0.20$ or $20 \%$. When price equals marginal cost, as with perfect competition, the numerator equals zero and hence $L$ is zero: i.e., there is no market power. ${ }^{7}$ Overall, a higher value of the Lerner index indicates greater market power. ${ }^{8}$ Because its use is standard, the Lerner index will be employed throughout this article for concreteness, but none of the analysis depends on this particular choice of a market power measure. ${ }^{9}$

Market power is the most frequently arising issue in competition law, it being an important element or aspect of the inquiry under most substantive rules. In the United States, some degree of market power must be demonstrated under all but a subset of per se doctrines on price fixing and related matters. "The offense of monopoly under $\S 2$ of the Sherman Act has two elements: (1) the possession of monopoly power in the relevant market and (2) the willful acquisition or maintenance of that power as distinguished from growth or development as a

control price, although significant elevations would be unprofitable, and a firm with great market power cannot simply ignore competitors and customers and, moreover, if it wishes to maximize profits, will feel compelled to select a single, particular price, just as would its low-power counterpart. See, e.g., PHILlIP AREEDA, LOUIS KAPLOW, \& AARON EDLIN, ANTITRUST ANALYSIS 485-86 (6th ed. 2004); Louis Kaplow \& Carl Shapiro, Antitrust, in, 2 HANDBOOK OF LAW AND ECONOMICs 1073, 1098 (A. Mitchell Polinsky \& Steven Shavell eds., 2007); see also DG Competition Discussion Paper on the Application of Article 82 of the Treaty to Exclusionary Abuses 123 (2005) [hereinafter DG Competition Article 82] (in elaborating that dominance requires the ability to behave independently of competitors and customers, states that "The notion of independence, which is the special feature of dominance, is related to the level of competitive constraint facing the undertaking(s) in question. For dominance to exist the undertaking(s) concerned must not be subject to effective competitive constraints. In other words, it thus must have substantial market power.”). These and other differences in definitions of market power will largely be ignored here.

${ }^{5}$ For example, in the presence of fixed costs, some would prefer to view market power as encompassing only elevations greater than necessary to recover those costs, particularly to the extent it is thought (feared) that a finding of market power might too readily lead to condemnation, without appropriate inquiry into whether the acts under scrutiny are in fact anticompetitive. For further discussion, see Kaplow, supra note 3, at 498-502.

${ }^{6}$ See, e.g., AREedA, HovenKAMP, \& Solow, supra note 4, at 118-19; Kaplow \& Shapiro, supra note 4, at 1080; Landes \& Posner, supra note 4, at 939, 941.

${ }^{7}$ Because the denominator is the price rather than marginal cost, the Lerner index has values somewhat different from what one might have expected. For example, suppose that price is $10 \%$ above marginal cost (e.g., $P=110$, $M C=100$ ); then $L=10 / 110 \approx 9 \%$. Price 50\% above marginal cost (e.g., $P=150, M C=100)$ yields an $L$ of approximately $33 \%$, and a price $100 \%$ above (double) marginal cost (e.g., $P=200, M C=100$ ) yields an $L$ of $50 \%$.

${ }^{8}$ In the limit, $L=100 \%$ implies an infinite price or a marginal cost of zero, so for finite prices and strictly positive marginal cost, we have $L<100 \%$.

${ }^{9}$ One could instead examine, for example, the fraction $P / M C$ (which equals $1 /(1-L)$ ), in which case perfect competition would be associated with an index value of 1 , price $10 \%$ in excess of marginal cost would result in a value of 1.1 , and so forth. Or one could consider $(P-M C) / M C$ (which equals $L /(1-L)$ ), which in turn is equivalent to $(P / M C)-1$, so perfect competition would (as with the Lerner index) have an index value of 0 , whereas a price $10 \%$ in excess of marginal cost would have a value of 0.1 , etc. Although these alternatives may seem a bit more straightforward to the uninitiated, all are substantially equivalent (since they are all monotonic transformations of $L$ ). The use of the Lerner index is conventional in economic analysis of the subject because it has simpler properties that render its use convenient when it comes to measuring market power. See, e.g., Landes \& Posner, supra note 4, at 939-52; Kaplow \& Shapiro, supra note 4, at 1080-86. 
consequence of a superior product, business acumen, or historic accident."10 EU Article 102 (formerly 82) prohibits the abuse of a dominant position, which clearly requires both a dominant position (which loosely corresponds to the possession of significant market power) and some form of abuse. Clayton Act $\S 7$ considers whether the effect of a merger "may be substantially to lessen competition, or to tend to create a monopoly," which under the standard methodology of the U.S. Merger Guidelines involves an inquiry into whether the merger is likely to raise prices substantially. ${ }^{11}$ EU merger policy is similar in this respect. ${ }^{12}$ Tying claims require demonstration of significant market power in the market for the tying product. ${ }^{13}$ And market power must be demonstrated in challenging some horizontal restraints in order to trigger application of the per se prohibition. ${ }^{14}$

These assessments refer sometimes to the level of market power, sometimes to the increment in market power, and sometimes to both. For example, monopolization inquiries tend to focus on the level of market power, although the magnitude of the anticompetitive effect may well be indicated by how much a challenged practice contributes to market power. Merger investigations usually emphasize the increment, although standard thresholds in merger guidelines contain both measures. Whether one or both is relevant and how or why is not a central concern here, ${ }^{15}$ and it will be convenient in the discussion to follow to refer in most instances to levels of market power, although the logic is equally applicable to changes. Thus, statements like "how much market power exists" or "how much market power is required" can also or instead be understood as referring to "how much increase in market power will take place" or "how much increase in market power is required." 16

The method by which market power is determined is an important subject but one not directly relevant here, where the focus is on the statement of legal threshold tests in terms of market shares and the resulting conflation of empirical and policy questions. ${ }^{17}$ Nevertheless,

\footnotetext{
${ }^{10}$ United States v. Grinnell Corp., 384 U.S. 563, 570-71 (1966).
}

${ }^{11}$ U.S. MERGER GUIDELINES, supra note 4, $\$ 1$ ("The unifying theme of these Guidelines is that mergers should not be permitted to create, enhance, or entrench market power or to facilitate its exercise." (market power being defined, as quoted in note 4 , in terms of price elevation)); $i d$. $\$ 4.1 .1$ (defining the relevant market as one in which a hypothetical monopolist "likely would impose at least a small but significant and non-transitory increase in price" (referred to as the SSNIP test)).

${ }^{12}$ See European Union, Guidelines on the Assessment of Horizontal Mergers, European Commission Regulation $139 / 2004$ (2004).

${ }^{13}$ See, e.g., U.S. Steel Corp. v. Fortner Enter., 429 U.S. 610 (1977); Jefferson Parish Hosp. Dist. No. 2 v. Hyde, 466 U.S. 2 (1984).

${ }^{14}$ See, e.g., Northwest Wholesale Stationers v. Pac. Stationary \& Printing Co., 472 U.S. 284 (1985).

${ }^{15}$ For further discussion, see Kaplow \& Shapiro, supra note 4, at 1183-86.

${ }^{16}$ Note also that the change in market power due, say, to a horizontal merger is the difference between the level of market power after the merger and the level that prevailed beforehand, so statements about increments can be related to statements about levels.

${ }^{17}$ For example, there are differences of opinion regarding whether and when one should employ merger simulations, undertake critical loss analysis (including a variant that assesses the existence of upward pricing pressure for mergers), rely on more informal impressions from sophisticated buyers, adjust analysis to incorporate dynamic competition, and so forth. See, e.g., Dennis W. Carlton, Revising the Horizontal Merger Guidelines, 6 J. COMPETITION L. \& ECON. 619 (2010); J. Gregory Sidak \& David J. Teece, Dynamic Competition in Antitrust Law, 5 J. COMPETITION L. \& ECON. 581 (2009). For present purposes, these disagreements are entirely immaterial for the reasons explained in the 
there is a significant indirect link. Specifically, the dominant method of making market power inferences is the market definition / market share paradigm: First, a relevant market is defined; next, the market share of the defendant firm or firms is measured; last, a market power inference is made from the market share in the selected market. ${ }^{18}$ Much of this article relates to the final step. For the present, two preliminary observations should be noted. One is that step three contemplates a market power inference from the market share, a familiar point that proves to be fundamental to the arguments that follow. Another is that use of the market definition / market share paradigm to measure market power might readily encourage thinking in market share terms (in ways that are criticized here), and, conversely, having a legal test denominated in market share terms may tend to encourage use of this paradigm for the assessment of market power (a practice criticized elsewhere). ${ }^{19}$ This interrelationship is revisited in part VI.

\section{B. Market Share Threshold Tests}

As section A explains, competition law often makes market power an important element in defining violations, and market power is generally understood to refer to the extent to which a firm or group of firms would find it profitable to elevate price. Accordingly, one might naturally expect market power requirements to be denominated in terms of price elevation. For example, a firm might be deemed to have monopoly power if it finds it profitable to raise prices at least twenty percent above a competitive level. (Likewise, if some rule involved temperature - perhaps certain perishables must be stored below a target temperature to limit bacterial growth - or speed, one would expect the command to be expressed in degrees Fahrenheit or miles per hour — or, equivalently, in degrees Celsius or kilometers per hour, which is to say, units of temperature or speed.)

This logical, straightforward state of affairs does not, however, often prevail. Instead,

text.

${ }^{18}$ See, e.g., Eastman Kodak Co. v. Image Technical Serv., Inc., 504 U.S. 451, 469 n. 15 (1992) (“Courts usually have considered the relationship between price in one market and demand in another in defining the relevant market. Because market power is often inferred from market share, market definition generally determines the result of the case."); AREEDA, HOVENKAMP, \& SOLOW, supra note 4, at 135 ("In resolving market or 'monopoly' power issues, the courts have typically relied heavily on market definition and on the defendant firm's market share of the market thus defined."); Jonathan B. Baker, Market Definition: An Analytical Overview, 74 ANTITRUST L.J. 129, 129 (2007) ("Throughout the history of U.S. antitrust litigation, the outcome of more cases has surely turned on market definition than on any other substantive issue. Market definition is often the most critical step in evaluating market power and determining whether business conduct has or likely will have anticompetitive effects."); Landes \& Posner, supra note 4, at 938 ("The standard method of proving market power in antitrust cases involves first defining a relevant market in which to compute the defendant's market share, next computing that share, and then deciding whether it is large enough to support an inference of the required degree of market power."); Robert Pitofsky, New Definitions of Relevant Market and the Assault on Antitrust, 90 CoLUM. L. REV. 1805, 1806-07 (1990) ("Definition of [a] relevant market is a critical analytical tool in antitrust enforcement because the legality of business conduct almost always depends upon the market power of the participants. . . Knowledgeable antitrust practitioners have long known that the most important single issue in most enforcement actions - because so much depends on it - is market definition."); RICHARD A. POSNER, ANTITRUST LAW 147 (2nd ed. 2001) ("The importance of concentration ratios in the administration of the antitrust laws makes the definition of the market in which to compute the defendant's market share critical.").

${ }^{19}$ The most aggressive attack appears in a companion article, Kaplow, supra note 3, which also cites prior literature. Although the central question in that article as well as most of the particular arguments differ, there is some connection between the two enterprises, as will be noted periodically below. 
market power requirements are ordinarily denominated as market share threshold tests. ${ }^{20}$ Most famous in the United States is probably Hand's pronouncement in Alcoa (quoted in the Introduction and examined in detail in part V). Subsequent courts and commentators, addressing both monopolization and attempted monopolization, likewise state the market power requirement as a market share threshold, ${ }^{21}$ and the practice in the European Union of defining dominance under Article 102 is similar. ${ }^{22}$ The market power requirement for tying is stated using market share. ${ }^{23}$ And the U.S. Merger Guidelines, followed in this respect by many other jurisdictions, ${ }^{24}$ articulate thresholds for varying levels of concern using an index (the Herfindahl-Hirschman Index, or HHI) that is defined in terms of market shares (an application discussed further in part $\mathrm{VI})^{25}$

In summary, courts, agencies, and commentators articulate market power requirements as market share tests. There is, to be sure, a fair amount of disagreement about what market share is deemed to be appropriate under a given legal rule. Furthermore (and of some relevance below), market share tests are often believed to have some flexibility, requiring somewhat higher or lower market shares (or increments to market shares) depending on the circumstances. Nevertheless, the central point for present purposes is that the metric employed in legal tests for market power is market share.

\footnotetext{
${ }^{20}$ Regarding Europe, see, for example, RICHARD WHISH, COMPETITION LAW 43-47 (6th ed. 2009) (stating that "it is interesting to consider the large range of situations in which EC and UK competition law require competition lawyers and their clients to consider market share figures for the purpose of deciding how to handle a particular case," and presenting a three-page table of market share thresholds followed by forty-four supporting notes).

${ }^{21}$ See, e.g., 3B Phillip E. AREeda \& Herbert HovenKAMP, ANTITRUST LAW: An ANALYsis OF ANTITRUST PRINCIPLES AND THEIR APPLICATION 392-94 \& n.19 (3rd ed. 2007) (collecting cases identifying levels of market share required in a monopolization case); $i d$. at 383 (stating the authors' preferred presumptive requirement of a share exceeding 70-75\% for five years); $i d$. at 441-43 \& n.57 (presenting cases articulating market share thresholds for attempted monopolization cases and offering their own market share recommendations); AREEDA, HOVENKAMP, \& SolOW, supra note 4, at 250-51 (summarizing and endorsing pronouncements by U.S. courts favoring strong presumptions of significant market share minimums in monopolization cases); Gregory J. Werden, Assigning Market Shares, 70 ANTITRUST L.J. 67, 71-72 \& n.24 (2002) (citing cases in support of the proposition that appellate courts require more than a $50 \%$ market share in monopolization cases).

${ }^{22}$ See, e.g., DG Competition Article 82, supra note 4, $\$ 31$ ("It is very likely that very high market[] shares, which have been held for some time, indicate a dominant position. This would be the case where an undertaking holds $50 \%$ or more of the market, provided that rivals hold a much smaller share of the market. In the case of lower market shares, dominance is more likely to be found in the market share range of $40 \%$ to $50 \%$ than below $40 \%$, although also undertakings with market shares below $40 \%$ could be considered to be in a dominant position. However, undertakings with market shares of no more than $25 \%$ are not likely to enjoy a (single) dominant position on the market concerned."'); MAHER M. DABBAH, EC AND UK COMPETITION LAW: COMMENTARY, CASES AND MATERIALS 330 (2004); KoRAH, supra note 4 , at $121-23$.

${ }^{23}$ See, e.g., Jefferson Parish, 466 U.S. at 26-27; 10 PhiLliP E. AreEdA, EINER ElHAuge, \& HerberT

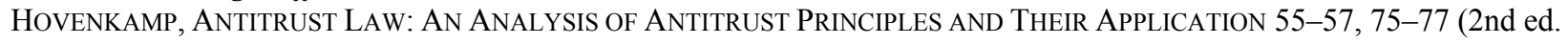
2004) (discussing required market share in Jefferson Parish and subsequent cases).

${ }^{24}$ See, e.g., Carlton, supra note 17, at 619 ("The [U.S.] Horizontal Merger Guidelines . . . have had an enormous influence not just on how U.S. antitrust agencies conduct merger policy but also on how courts and antitrust agencies throughout the world make decisions about the antitrust consequences of mergers.").

${ }^{25}$ U.S. Merger Guidelines, supra note 4, §5.3; 4 Phillip E. AreEdA \& Herbert HovenKAmP, ANTITRUST LAW: AN ANALYSIS OF ANTITRUST PRINCIPLES AND THEIR APPLICATION 170-80 (2nd ed. 2006) (summarizing the Merger Guidelines' approach, offering the authors' views thereon, and describing courts' endorsement of the Merger Guidelines' thresholds).
} 


\section{TWO DISTINCT QUESTIONS; NO MARKET SHARE ANSWERS}

As the heading suggests, this part advances multiple claims. Initially, it is argued that there are two distinct questions regarding market power in competition law applications. Question 1 involves empirical assessment: How much market power is present in a given situation? Question 2 involves a legal policy judgment: How much market power should be required under a given substantive prohibition? These questions will be elaborated in sections A and $\mathrm{B}$, respectively, making clear what each involves and how they differ. As mentioned in the introduction, even though the difference is obvious and understood by everyone at some level, it is important to examine each to sharpen the distinction since the two questions are routinely conflated when market power requirements are stated as market share threshold tests.

Another central claim in this part is that market shares are not proper answers to either of these two questions. To an extent, this point should also be obvious since market shares are not even in the proper units; on its face, answering either of the two market power questions with market share percentages involves a category mistake. As a consequence, there is a strong basis for the view that we should abandon the practice of giving market share answers in both settings. Moreover, the discussion of how market share relates to these two distinct questions will reveal the manner in which they become conflated when discussing and applying market share threshold tests, a feature examined further in subsequent parts of this article.

\section{A. Empirical Assessment}

As stated, question 1 is empirical: How much market power is present in a given situation? To answer such a question, it is important to remember what we mean by market power. As discussed in section II.A, it is the extent by which price is elevated above a competitive level (specifically, with the Lerner index, the fraction of the price that is in excess of marginal cost). Accordingly, an answer to the question "how much market power?" would be in units or percentages of price elevation.

What sort of answer to the "how much market power?" question is "the market share is $57 \%$ "? On its face, it is an odd answer, a category mistake. ${ }^{26}$ Although it is a percentage and the Lerner index can be stated as a percentage, it is a percentage of the wrong thing. The answer is not in the units the question poses. It is as if, when asked "how much do you weigh?," a person answered "6 feet tall." Or "what mileage does your vehicle get?" is answered with "a 2.5 liter displacement engine." Or "what is the price of this dress?" with "it's made of silk." Anyone hearing such answers would think that the respondent was not listening, was confused, or perhaps did not understand the language very well. Note that, in each of these illustrations, the answer is related to the question; it is hardly random. In particular, each response is an important factor bearing on an appropriate answer to the question. Still, these answers are blatantly not in the terms (units) put by the question.

\footnotetext{
${ }^{26}$ "Category mistake" is a term used by philosophers to refer to speaking of one thing in language that is appropriate only for something else that is qualitatively different.
} 
These off-point answers would, on reflection, be coherent if there existed a uniform relationship between the units of the question and of the answer. Think about temperature being given in degrees Fahrenheit versus Celsius. Question: "How many degrees Fahrenheit is it outside?" Answer: "20 degrees Celsius." We still would find the interchange a bit odd, but not entirely disturbing. After a quick conversion (20 degrees Celsius is 68 Fahrenheit), we could proceed. Even a slightly looser connection would be serviceable for many purposes, even if inferior to responses in proper terms. If all who are 6 feet tall weigh nearly the same amount (regardless of gender, bone structure, eating and exercise habits), if 2.5 liter engines got approximately the same mileage (independent of other engine features and the weight of the vehicle), and if all silk dresses were about the same price (regardless of type of silk, cut, designer), there would be some annoyance but little real problem. In these examples, however, such is emphatically not the case. As suggested, the proffered responses are in terms of a significant factor bearing the answer to the question, but since there are other factors that can have a substantial influence, the given replies fall short. ${ }^{27}$ Likewise with market power and market share.

To begin, there is the well-known problem that the significance of market share depends tremendously on the market definition. A firm may have a $90 \%$ share of a narrow market but only a $20 \%$ share of a broader market (and a minuscule share of an even broader market). This problem is purportedly addressed by limiting uses of market share figures to the so-called relevant market, that is, the market defined properly according to some criterion. This poses a substantial difficulty, but let us set this part of the problem to the side and suppose that there is an agreed-upon conception of what constitutes the correct market definition and that all further discussion is confined to market shares in properly defined markets. ${ }^{28}$

Suppose, then, that we are examining a properly defined market. Is it now true that market share (alone) gives a precise measure or at least a fairly narrow range of possible values of extant market power? Such may have been believed decades ago, but even then it was often said that market shares only provide an indication of market power, one that needs to be interpreted in light of other factors. ${ }^{29}$ Subsequent work has emphasized this point, and it is now considered to be elementary. ${ }^{30}$

\footnotetext{
${ }^{27} \mathrm{~A}$ contrasting example would be a question asking the mass of an object and an answer stating its weight. If the questioner presumes that the weight refers to that on the surface of the earth, and taking into account that variation depending on, say, the elevation where the weight was measured is fairly small and probably of trivial importance for many purposes, the answer might well be sufficient. Thus, sloppiness involving answers not even in the proper units of the question are tolerated in some settings.

${ }^{28}$ Whether coherent answers of the sort usually imagined really exist in a meaningful sense is challenged in Kaplow, supra note 3, but those arguments or others casting doubt on the market definition process are ignored for present purposes.

${ }^{29}$ United States v. General Dynamics Corp., 415 U.S. 486 (1974), is taken to stand for this view, and it in turn cited Brown Shoe Co. v. United States, 370 U.S. 294 (1962), for the proposition that "statistics concerning market share and concentration, while of great significance, [are] not conclusive indicators of anticompetitive effects." Id. at 498.

${ }^{30}$ The 1981 article by Landes and Posner, supra note 4, is most known for elaborating this principle. See also Schmalensee, supra note 4, at 1800-01 ("Even if a well-defined market can be identified, a firm's share of such a market may nevertheless give a seriously distorted indication of the firm's market power."); Pitofsky, supra note 18, at 1810-11 ("Most important, it does not necessarily follow that a firm accounting for $90 \%$ of sales in a properly defined market has substantial market power, nor that a firm with only $30 \%$ of sales in a properly defined relevant market lacks market
} 
The reasons are familiar. First, even within properly defined markets, the market elasticity of demand can vary considerably. Second, even holding that elasticity constant, the ability of other firms - rivals and prospective entrants, including producers of related products who may be able to convert their facilities - to expand supply in response to a price increase differs enormously. In some instances, notably with constant marginal costs and no binding capacity constraints, their ability is unlimited (preventing any price increase) and in others, it is negligible (think of gasoline refineries and electricity generation). Landes and Posner's article illustrates the phenomenon. For example, in one of the columns in their first table, as the hypothesized market elasticity of demand rises from 1.0 to 1.5 to 2.0 , the market share necessary for a dominant firm to impose a given level of deadweight loss increases from $49 \%$ to $61 \%$ to $70 \%{ }^{31}$ Put another way, a $49 \%$ share in the first market conveys the same market power as a $70 \%$ share in the latter market; hence, a given share, say $49 \%$, conveys significantly different levels of market power in the two different markets. In their second table, they consider two possible values for the market elasticity of demand and rivals' elasticity of supply. When both are at their high levels, the market share required for a $20 \%$ price elevation is $61 \%$, but when both are at their low levels, a share of $23 \%$ suffices. $^{32}$ The notion that some given market share, say, $50 \%$, conveys a particular level of market power or even a fairly narrow range is emphatically rejected. (Just like it is false that all 6-foot tall people have the same weight or nearly so.)

To summarize, question 1 ("how much market power exists") calls for an empirical assessment. Given the definition of market power, a proper answer needs to be in terms of the degree of price elevation. Market share is not even in the right units. It does not on its face answer the question. To be sure, market share bears on the extent of market power, but it is only one of a number of significant factors. Moreover, the market share (even in a properly defined market) does not allow even a rough approximation of the extent of market power.

\section{B. Legal Policy Judgment}

Question 2, recall, involves a legal policy judgment: How much market power should be required under a given substantive prohibition? It takes little analysis to show that this question is, on one hand, quite distinct from question 1, yet market shares do not constitute proper answers for essentially the same reason given in section $\mathrm{A}$.

power."); Kaplow \& Shapiro, supra note 4, at 1187-88 (the supposition "that a given share in a properly defined market conveys the same market power, regardless of the market[,] is emphatically false"). The view that market shares require interpretation is not confined to the United States. See, e.g., DG Competition Article 82, supra note 4, 930 ("In any event, the Commission interprets market shares in the light of likely market conditions, for instance, whether the market is highly dynamic in character and whether the market structure is unstable due to innovation or growth."); id. ๆ32 ("The strength of any indication based on market share depends on the facts of each individual case. Market share is only a proxy for market power, which is the decisive factor. It is therefore necessary to extend the dominance analysis beyond market shares, especially when taking into account the difficulty of defining relevant markets in Article 82 cases ....").

${ }^{31}$ Landes \& Posner, supra note 4, at 955 tbl.1 (column for a market size of \$200 million).

${ }^{32} \mathrm{Id}$. at 958 tbl.2; see id. at $947-48$ ("Thus the degree of market power in this example for a firm with an $8 \%$ market share is identical to that of a firm with an $80 \%$ share in a different market, because of offsetting differences in demand elasticities."). 
Question 2 directs us to consider why competition law often requires market power in the first place. ${ }^{33}$ Generally, the justification concerns the balancing of costs due to diminished competition and benefits often involving efficiencies, avoiding false positives and concomitant adverse chilling effects, and economizing on administrative costs. Sherman Act $\$ 2$ and EU Article 102 are directed (in significant part) at single-firm conduct. Because such conduct is ubiquitous and the possibility of errors is significant, it is necessary to reduce the settings in which firms' practices are scrutinized, using some combination of screening many cases at the outset and insisting ultimately on demonstration of nontrivial harm in most settings. Many desirable practices, indeed those we most wish to encourage (higher quality products at lower prices), tend to disadvantage competitors, and it is often difficult to separate beneficial acts from improper exclusion, so requiring significant market power can helpfully eliminate many cases that should fail and at only modest sacrifice in terms of permitting anticompetitive harm. For horizontal mergers, the reasoning is similar. Many mergers entail efficiencies (however difficult they may be to demonstrate), and a permissive stance toward mergers facilitates the market for corporate control, which disciplines managers and provides an important exit strategy for entrepreneurs, who may value it ex ante. Accordingly, mergers are best permitted unless there are likely to be notable anticompetitive effects.

In these and other settings, competition policy seeks to establish market power requirements of varying degrees of specificity regarding the type of legal prohibition (e.g., monopolization versus horizontal mergers) and particular facts of the case. Generally, what is desired is a certain level of plausible anticompetitive effect, usually measured in terms of the price elevation that is created or maintained as a consequence of the practice under scrutiny. That of course is why the element or screen is phrased in terms of market power, defined as the ability to profitably elevate price.

Having clarified question 2-what it asks and why - the two claims advanced in this part are quite apparent. First, this question is qualitatively distinct from question 1. Question 2 ("how much market power should be required") is normative, calling for a legal policy judgment, whereas question 1 ("how much market power exists in a given situation") is positive, that is, descriptive, calling for an empirical assessment. ${ }^{34}$ The sort of evidence and analysis required to answer each differs greatly, even though, to apply the legal standard (the answer to question 2), one must ultimately do the empirical assessment (that is, answer question 1).

Second, it is again apparent that market share is no answer, this time to question 2 . The simple reason is that question 2 - like question 1 - is asking about market power. Therefore, a market share answer is in the wrong units, involving a category mistake: the same mistake. Furthermore, as section A reminds, even if one seeks to convert market shares into market power via proper economic inferences, the resulting answers for a given market share vary too much for

\footnotetext{
${ }^{33}$ See, e.g., id. at 952-58; Kaplow \& Shapiro, supra note 4, at 1181-86.

${ }^{34}$ Also, question 2 poses a general standard whereas question 1 involves a particular application. The more context-specific is the legal standard, however, the smaller this difference would be. Existing legal standards and those generally favored by commentators tend to have a substantial degree of generality, so the gap on this dimension is sizeable. This point receives scant attention here because it is not at the core of what goes wrong when the two questions are conflated.
} 
market share to be used even as a crude approximation. This point holds for question 2 as well. If a legal standard demands a market share of $50 \%$, that could involve a market power requirement of a $2 \%$ elevation or a $70 \%$ elevation, or really any other elevation for that matter. Put more directly, if one's legal policy judgment is that the law on monopolization should insist on enough market power that the dominant firm could, say, elevate price at least $20 \%$, what market share would one require? 20\%? 95\%?

Consider a further, somewhat fanciful analogy. Suppose that a government speed limit for a road stated that a vehicle's engine's RPMs should not exceed 2000. Again, RPMs are positively correlated with our normative target, speed, but the relationship is noisy since it depends on the mass of the vehicle, the power of the engine, whether one is going up or down hill, and so forth. It would be remarkable if such a mismatch escaped expert commentators' attention; indeed, ordinary drivers would be perplexed. That is why the analogy is fanciful. However, since the analogy seems logically apt, it drives home the point that it does not make sense to answer the legal policy question about market power in terms of market shares.

An additional difficulty is worthy of note. As is familiar, market share thresholds are often stated as presumptive or involving ranges. Perhaps a $50 \%$ share ordinarily is sufficient for dominance, but in some markets the requisite share may be $55 \%$ or $60 \%$, or possibly even more, but in other settings maybe only $45 \%$ or $40 \%$ would be deemed necessary. The problem is that this way of talking - for all its seeming virtues of providing flexibility in a complex world - is incoherent. Since the standard approach neither indicates how much market power is required nor how much market power we think is associated with a given share, how can we offer a logical basis for determining when to deviate from the norm, in what direction, and by how much? For example, it might make sense to demand a higher market share when the normal share conveys less market power than we had in mind, but if we never said how much price elevation was required (we only said "a 50\% market share"), how can we even in principle state when this is the case $?^{35}$ Indeed, even ignoring atypical circumstances, one can ask how we ever make the move from the sort of legal policy analysis described just above to a statement of a presumptive market share threshold.

In sum, we have two distinct questions: how much market power is required and how much is present in a given case. Both ask about the extent of market power, that is, price elevation. Yet both are conventionally answered in the language of market shares. This kind of response fails to address either question directly and does not appear capable of providing a meaningful indirect answer. The next part seeks to offer a solution, one that turns out to be clarifying but in a manner that further advances the case against denominating legal thresholds in terms of market shares.

\footnotetext{
${ }^{35}$ A qualitatively different reason to deviate from the presumptive market share threshold would be that a different practice is under scrutiny, for which it may be optimal to require more or less market power. In that case, we can equivalently suppose that we have a longer, more refined list of market share requirements, perhaps one for each type of practice.
} 


\section{STANDARD REFERENCE MARKET AS A CLARIFYING CONSTRUCT}

Part III suggests that, if one is limited to using market shares in the usual way, it is impossible to offer intelligible answers to either the empirical question of how much market power exists or the legal policy question of how much market power should be required. To further motivate the present analysis, recall that this communication problem is compounded by the fact that market share threshold tests are ordinarily stated as flexible presumptions rather than fixed rules. Accordingly, we would like to be able to assess statements like: "Indeed, the defendant's market share of $55 \%$ is lower than what we might usually require, but in this market it conveys as much power as we would ordinarily associate with a much greater market share." Such an evaluation likewise seems difficult to undertake without a way of translating more directly between market shares and market power. Thus, what does it mean to say that some level of power is "as much ... as we would ordinarily associate with a much greater market share"?

Section A introduces the construction of a standard reference market as a means of bridging the market share / market power communications gap. As section B explains, the method does work in the literal sense that it provides a means of translation between these unlike concepts that are measured in qualitatively different units. On the other hand, it does so by essentially doing away with market share in answering both the empirical and the legal policy questions ${ }^{36}$ This result should not, however, be a surprise since we already understand that market share does not really provide a proper answer to either question.

\section{A. Construction}

The task is to devise a common method of converting directly between market power and market share. It would be like a language translation exercise if our problem was akin to Fahrenheit-Celsius conversion, involving like to like. But, as part III emphasizes, the challenge is much greater because we are converting different concepts measured in different types of units. Nevertheless, it can be done.

The proposed method is to employ what will be referred to as a standard reference market. This is to be understood as a hypothetical market constructed for use as a common benchmark. It is a market in the sense that there will be market shares that will correspond to levels of market power, and we will design it so that there is a unique, one-to-one correspondence between share and power. It is a reference to be used for translations in market share / market power discussions. And, importantly, it is standard, meaning that the same reference point needs to be used in all such discussions within or between adjudicators, agencies, lawyers, expert witnesses, business actors, and commentators.

\footnotetext{
${ }^{36}$ For the legal policy question, market share no longer plays any real role. For the empirical question, the answer is no longer in market share terms in any meaningful way; nevertheless, because market share is a fact that feeds into market power inferences and the empirical question is about market power, market share would play whatever factual role is appropriate under the pertinent economic analysis of the situation. See, e.g., Kaplow, supra note 3, at 447-59.
} 
The notion of a standard reference market is implicit in some discussions of market shares and market power. Whenever reference is made to the degree of market power that is "ordinarily" or "typically" conveyed by some market share, or that which "normally" exists or is present "on average," it is presumed that some sort of reference point exists. ${ }^{37}$ (Consider, for example, the illustration in the introduction to this part.) Yet, even though some such benchmark is necessary to render these sorts of statements comprehensible, it is never made explicit. ${ }^{38}$ Now we will.

Think of a standard reference market as a particular hypothetical market in which there is a determinate relationship between market share and market power. Equivalently, a standard reference market can be depicted as a table, with one column indicating market shares and an adjoining one indicating levels of market power. For example:

Table 1: A Standard Reference Market

\begin{tabular}{|c|c|}
\hline $\begin{array}{c}\text { Market } \\
\text { Share }\end{array}$ & $\begin{array}{c}\text { Market } \\
\text { Power }\end{array}$ \\
\hline $0 \%$ & $0 \%$ \\
\hline $20 \%$ & $3 \%$ \\
\hline $40 \%$ & $10 \%$ \\
\hline $60 \%$ & $20 \%$ \\
\hline $80 \%$ & $35 \%$ \\
\hline
\end{tabular}

In this abbreviated illustration, ${ }^{39}$ the left column indicates market share, measured in the usual way ${ }^{40}$ and the right column is the Lerner index (although it could just as well be presented using some other measure of market power, such as the ratio of price to marginal $\left.\cos ^{41}\right)$.

Such a table enables easy two-way conversions. If a market share threshold test indicates a minimum market share of $60 \%$ (and, we are now supposing, the test was derived with table 1

\footnotetext{
${ }^{37}$ See id. at 427-28 n.48 (noting the limited prior history of the idea); see also Louis Kaplow, The Accuracy of Traditional Market Power Analysis and a Direct Adjustment Alternative, 95 HARV. L. REV. 1817, 1819-21 (1982) (employing such a notion as a basis for criticizing Landes and Posner's claim that the use of market shares to infer market power systematically involves the overstatement of such power).

${ }^{38}$ It should be clear that, although criticism is directed at these sorts of statements, they are notably superior to the more typical discussions under which there is not even a suggestion of what might be imagined by comments about the degree of market power supposedly conveyed by some market share.

${ }^{39}$ Obviously, to be complete, the table would need to include all omitted values; more precisely, since any real number between 0 and $100 \%$ (inclusive) is possible for market share, we would need a two-dimensional graph to depict a curve relating market share and market power.

${ }^{40}$ There are complications concerning, for example, whether to measure market shares using the number of units sold or their value, but they are set to the side for present purposes.

${ }^{41}$ See supra note 9 (discussing alternatives to the Lerner index, including $P / M C$ ).
} 
in mind), we know that the requisite market power is a $20 \%$ price-cost margin (Lerner index). We would then analyze all the factors in a given case (including the actual market share, whatever it might be, in our chosen relevant market) to determine whether at least that much market power is present. If one wished to undertake policy analysis to determine an appropriate market power requirement, the work could proceed entirely in the language of market power, and, when a target was decided upon, it could be translated into a market share threshold using the table.

If in some other case we have determined that our best estimate of market power is a price-cost margin of $10 \%$, we can use table 1 to see that this corresponds to a $40 \%$ market share in our standard reference market and proceed accordingly. In undertaking our analysis of market power in such a case, we could conduct our assessment purely in terms of market power, making the translation into market share at the very end.

It is apparent that, if such a table is employed by all, the communication problem can be solved, on which more in section B. It should also be noted that it really does not matter what table is used, as long as it has certain basic properties (notably, higher market shares are associated with greater market power ${ }^{42}$ ) and the same table is used by all. Nevertheless, it is instructive to consider briefly some of the ways that such a table might be constructed.

One set of approaches would construct the table from reality. A particular, actual market at a specific place and time might be employed. One would determine best estimates of market power associated with various market shares and place such figures in the second column. A challenge, which makes this exercise hypothetical, is that a single, actual market will have at most a single dominant firm with a single market share.

Perhaps more appealing would be to use levels of market power that are on average associated with each market share. Constructing such a table would be daunting. One would need to repeat the operation just described for every existing market, confronting market definition questions in each instance, and still nearly all the figures would be hypothetical. ${ }^{43}$ Moreover, the answer would change over time (with technology, consumer tastes, trade barriers, and the like), although a given answer could be frozen in place for use in the table.

In light of these considerations, an arbitrary table might be sensible. Perhaps one would

\footnotetext{
${ }^{42}$ It is also necessary that the market power column has sufficient range. For example, if a $100 \%$ market share was associated with market power of $60 \%$, there would be no market share to assign when market power is $70 \%$. (The solution is to have market power approach infinity, which corresponds to a Lerner index of 1.0 (see supra note 8), as the share approaches $100 \%$. In practice, a finite bound will suffice as long as it is at least as high as the greatest level of market power we would ever wish to require, for once past that point, any truncation would be unimportant, at least for this particular task.)

${ }^{43}$ For this case or the preceding one in which a particular market is selected, one could instead collect data on the market elasticity of demand and on the elasticity of supply for each market in question and use that to compute the Lerner index that corresponds to each market share (setting to the side the complication that there is no single value for either elasticity in a given market since the elasticities depend on price and output, which in turn are influenced by market share). See, e.g., Landes \& Posner, supra note 4, at 945 (equation 3); Kaplow \& Shapiro, supra note 4, at 1080-82 (equations (1) and (2)).
} 
use a textbook market, although there is really no such thing. (A particular textbook might have particular demand curves and cost functions, which would have implications for the market share / market power relationship, but there is no standard textbook market as such.) Or one could simply make up figures, which is what was done to construct table 1.

\section{B. Implications}

Section A shows that one can construct a standard reference market that, if used by all, renders the market share / market power translation problem (which seemed intractable in principle) no more difficult than Fahrenheit-Celsius conversions. The problem is that, in so doing, we have discarded the use of market share for both of our questions. The right, market power column in the table is the real column, and the left, market share column corresponds neither to the share that exists in a given case nor to the share we are actually requiring in any meaningful sense. It is a totally artificial, placeholder construction there merely allows us to utter the words "market share" followed by some number, which figure is meaningless in itself and finds its true signification only when translated into market power.

To elaborate, begin with question 1, the empirical assessment of how much market power exists in a given case. We may well have chosen to define a relevant market and examine the market share in that market (call this $M S_{A C T U A L}$ ). But we do not use that market share for purposes of applying the pertinent market share threshold test. Instead, the only relevance of that actual market share is as one of the factors that goes into formulating our best estimate of the actual market power in the case at hand. We would also consider the market elasticity of demand and supply responses (of existing rivals or entrants). Then, given our best estimate of market power, we look up that figure in the right column of the table and find the corresponding market share in the left column of our standard reference market (call this $M S_{S R M}$ ). This market share, remember, is an entirely hypothetical figure. (Or, if it is an actual figure, such as if the table is constructed using averages across all markets, it is not in any case the value for the market share in the case under examination.) Then, to apply the legal test, we ask whether $M S_{S R M} \geq M S_{L T}$ (where the subscript $L T$ refers to the legal threshold or legal test for the category of case under consideration). To repeat the key point here, the legal test uses $M S_{S R M}$, not $M S_{A C T U A L}$. If we used the latter on the table, we would be looking up the wrong figure. As emphasized in section III.A, because the market power implications of any given market share

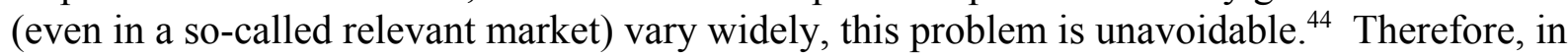
order to make intelligible a market share answer to question 1 about how much market power

\footnotetext{
${ }^{44}$ To elaborate (briefly, since market definition is not the subject here; see Kaplow, supra note 3, for an in-depth treatment), this difficulty does not derive from choosing the wrong market (whatever that means) as the relevant one, but from the substantial lumpiness of market definition. Only by a lucky coincidence would there be a naturally available market definition that would yield a value for $M S_{A C T U A L}$ that just happened to equal (or be close to) the pertinent $M S_{S R M}$ in our table. See Kaplow \& Shapiro, supra note 4, at 1188. There is an out, presented in Kaplow, supra note 3, at 474-75 n.75, involving the use of jerry-rigged markets. Instead of defining a relevant market in the ordinary way, one can use the best estimate of market power to determine $M S_{S R M}$ from the table, and then include or exclude portions of markets (possibly excluding parts of the narrowest, homogeneous goods market if necessary to get a high enough market share), so that we could produce a value of $M S_{A C T U A L}$ that equalled $M S_{S R M}$. It is obvious, however, that this exercise is entirely circular and pointless since we just define $M S_{A C T U A L}$ as the market share that equals $M S_{S R M}$. That is, $M S_{A C T U A L}$ would no longer be an actual market share in a so-called relevant market in any conventional sense.
} 
exists, we have to discard the actual market share answer and substitute an artificial one that is chosen to yield the right answer in an openly circular fashion.

Next consider question 2, the legal policy judgment of how much market power should be required under a given substantive prohibition. As section III.B explains, such a judgment embodies a cost-benefit assessment in which market power is defined and measured in the ordinary way, so any conclusion will be denominated in terms of market power. The table permits us to translate this conclusion into a market share. But this market share is, by definition, $M S_{S R M}$, which as just explained has nothing in particular to do with $M S_{A C T U A L}$ in any given case.

To further dramatize this point, recall that the construction of table 1 is arbitrary. Any table with the basic properties would do. For example, we could just as easily have used:

Table 2: An Alternative Standard Reference Market

\begin{tabular}{|c|c|}
\hline $\begin{array}{c}\text { Market } \\
\text { Share }\end{array}$ & $\begin{array}{c}\text { Market } \\
\text { Power }\end{array}$ \\
\hline $0 \%$ & $0 \%[0 \%]$ \\
\hline $20 \%$ & $6 \%[3 \%]$ \\
\hline $40 \%$ & $20 \%[10 \%]$ \\
\hline $60 \%$ & $40 \%[20 \%]$ \\
\hline $80 \%$ & $70 \%[35 \%]$ \\
\hline
\end{tabular}

(The figures in square brackets are those from table 1.) Now, if we had originally (with table 1) stated a market share threshold, $M S_{L T}$, of $60 \%$, that would have made sense if and only if we had determined that the minimum requisite market power should be $20 \%$. But, if we were using table 2 instead, we would need to declare that $M S_{L T}$ is only $40 \%$. And likewise for any other table we might adopt.

Therefore, whether considering question 1 or question 2 , the market shares that answer our questions are not the actual market shares in the market under consideration but are artificial shares in the standard reference market. These shares could take on any values, depending on how we defined that hypothetical market, that is, which table we chose to employ.

To summarize, the use of the standard reference market construct, which is helpfully associated with some common translation table, does solve the problems with which we began. Our two distinct questions, one involving empirical assessment and the other legal policy judgment, are kept separate. Each is answered. Although the answers are still in terms of market shares — which part III indicates to be highly problematic — we are now able to make sense of those market share answers with regard to both questions. 
But, in accomplishing all this, we have entirely eliminated any meaningful sense in which we are really using a market share threshold test, which is what competition law normally purports to do. Both of our questions are, at bottom, being answered in terms of market power, not market share. The use of market share language, made coherent by the device of the standard reference market, is an artifice. The reason that nothing is lost in the translation in either direction between market share and market power is that there is nothing left of market share. It has become a mere placeholder for a level of market power. The standard reference market is simply a convention under which everyone agrees that, for example, a $60 \%$ market share means $20 \%$ market power (in the case of table 1). Actually deploying this mechanism would clearly be pointless, as it requires some additional mechanical steps that accomplish nothing, except possibly obscuring communication because observers must keep in mind that the market share figures used in this process are artificial (and distinguish them from actual market shares that might be used when formulating a best estimate of market power in answering question 1 in pure market power terms). Nevertheless, we should not forget that the use of the standard reference market does have the virtue that it produces correct answers to each of our distinct questions, ${ }^{45}$ whereas standard methods that use actual market shares fail at both and (as part $\mathrm{V}$ further shows) often conflate the two questions in the process.

Before concluding the discussion, it is worth reflecting on the point that the standard reference market construct works only if everyone speaks the same language, which is to say, uses the same translation table. For question 1, in factfinding, we need lawyers, expert witnesses, agencies, and adjudicators to be on the same page, literally. If some are using table 1 and others table 2 or some other unspecified table, serious error can result. Similarly, for question 2, commentators and law-writers (whether legislatures, agencies, or courts) need to have a common reference point when forming and promulgating legal policy judgments about market power - that is, if such rules are to be stated in market share terms. And, of course, each of these two groups needs to coordinate with the other.

Current competition law discourse and practice fails miserably in this respect. The situation is worse than that with the Tower of Babel. At least there, everyone was aware that their utterances were mutually incomprehensible. With market share thresholds, everyone seems to write and speak as if others have a common understanding. The translation problem presented in part III is almost entirely unrecognized. Moreover, it is clear that participants have not constructed standard reference market tables, much less by stunning coincidence all the same ones. At best, everyone has their own vague, implicit conception (feeling might be more apt) of whether a given market share is associated with a small, medium, or large amount of market power - and of how much market power one might mean by small, medium, or large.

To consider the extent of this problem, suppose that one administered surveys with

\footnotetext{
${ }^{45}$ This part can be viewed as a formal, logical, semantic enterprise, attempting to determine what must be assumed in order to render coherent ordinary competition law discourse - which answers two types of market power questions with market shares, a category mistake. Not only does the standard reference market construct succeed, but it seems clear that there is really no other way to do so (that is not essentially equivalent to the one presented here).
} 
questions like the following: ${ }^{46}$

- How much market power (profitable price elevation by a dominant firm) typically exists when the dominant firm has an $80 \%$ market share in a properly defined market?

- $\quad$ Suppose that a dominant firm finds it maximally profitable to set its price $30 \%$ above marginal cost. What is your best guess as to its market share (in a properly defined market)?

Readers can ask themselves how they would answer these questions, if forced to do so. ${ }^{47}$ At least as interesting, consider how we might expect various others (judges, agency heads, commentators, expert witnesses) to answer these same questions. ${ }^{48}$ In particular, it is useful to contemplate how wide a range the answers would span and whether most would tightly cluster on some figure. Does anyone have confidence that they would?

\section{DEMONSTRATING CONFLATION: UNPACKING ALCOA}

The claim that standard use of market share thresholds conflates the two distinct questions of empirical assessment and legal policy judgment is nicely demonstrated by examination of Hand's famous pronouncement in Alcoa of the market share thresholds for monopolization under Sherman Act $\S 2 .{ }^{49}$ As emphasized at the end of this part, however, the logic in no way depends on the particular's of Hand's phrasing but rather is generic to any statement of a market share legal threshold.

As quoted in the Introduction, Hand famously stated that ninety percent "is enough to constitute a monopoly; it is doubtful whether sixty or sixty-four percent would be enough; and certainly thirty-three per cent is not." 50 This proclamation constitutes a typical statement of a market share threshold test. The question to be considered is what this statement could possibly

\footnotetext{
${ }^{46}$ Similar questions can be put more in the language of question 2 on the legal threshold: "Suppose that the market power threshold for monopolization or dominance is that market share must be at least $80 \%$. What is the minimal price elevation that would meet this test?" Or: "Suppose that the profitable price elevation by the dominant firm is shown to be $30 \%$. What is the highest market share threshold that would be satisfied?"

${ }^{47}$ No doubt, many would resist answering, insisting that more facts and circumstances would need to be known. But one could demand a best guess, ask the respondent to assume that all else is at typical or average levels, or simply ask what one thinks others would say if forced to guess.

${ }^{48}$ As a suggestive illustration, consider David T. Scheffman \& Pablo T. Spiller, Econometric Market Delineation, 17 MANAGERIAL \& DECISION ECON. 165 (1996). In their econometric analysis of margarine and butter, they find that the elasticity for margarine is -3.5 , which they deem "high . . . indicating that margarine is not a relevant market," $i d$. at 175 . Yet they do not explain why this elasticity should be viewed as high rather than low or medium, or why it indicates that the relevant market is broad rather than narrow (just margarine). Indeed, if one applies the hypothetical monopolist test (so the share is $100 \%$ ) and uses the standard formula, the Lerner index (equal to one divided by the market elasticity of demand; setting to the side supply responses) is approximately 0.29 and the implied degree to which price would exceed marginal cost is $40 \%$. They implicitly view this degree of elevation as reflecting insubstantial market power, whereas we might suppose that many would take this to be quite substantial market power.

${ }^{49}$ For suggestive precursors, see AREEDA, KAPLOW, \& EDLIN, supra note 4, at 508; AREEDA, KAPLOW, \& EDLIN, TeAcher's Manual_-Antitrust AnAlysis: Problems, TeXt, CASES 189-90 (2004); and Kaplow \& Shapiro, supra note 4 , at 1187 \& n. 170 .

${ }^{50} 148$ F.2d at 424 . On the prominence of this statement, see note 1.
} 
mean in light of the previous analysis in this article, in particular the point that the test is denominated in market shares, which are not measures of market power.

The discussion in part IV indicates that use of a standard reference market can help make the connection coherent. The sort of tables presented there are also valuable even when no standard reference claim is asserted. The two questions we seek to disentangle - corresponding to our two questions throughout - are how much market power Hand thought was associated with the various market shares in the statement (empirical assessment) and how much market power did Hand believe or deem to be sufficient for the monopolization offense (legal policy judgment). As we will see, despite the seeming precision of Hand's holding, neither question is answered. That is, we have a very precise answer, but it does not properly respond to any real question of interest.

Initially, suppose that Hand believed the following about the actual market power associated with the different market shares in the aluminum industry in that time period.

Table 3: (Middle) Beliefs about Actual Market Power in Alcoa

\begin{tabular}{|c|c|}
\hline $\begin{array}{c}\text { Market } \\
\text { Share }\end{array}$ & $\begin{array}{c}\text { Market } \\
\text { Power }\end{array}$ \\
\hline $33 \%$ & $5 \%$ \\
\hline $60 / 64 \%$ & $15 \%$ \\
\hline $90 \%$ & $30 \%$ \\
\hline
\end{tabular}

(The explanation for the adjective "middle" in parentheses of the table heading will be clear in the next paragraph.) These beliefs are not in themselves sufficient to fill out Hand's statement, for we also need to know the market power legal threshold he thought appropriate. Given his confidence about the $90 \%$ and $33 \%$ market shares and doubt about $60 / 64 \%$, we might imagine that he thought the law should require market power somewhat above $15 \%$, but he was not quite sure precisely how much. Alternatively, he might have had a definite view on the legal requirement, perhaps he thought it was $17 \%$, but entertained uncertainty about whether the market power associated with the $60 / 64 \%$ share was $15 \%$ or perhaps somewhat lower or instead nearly $20 \%$ (which he thought to be less likely, but possible, and there was no need to resolve the question). These two sets of beliefs about actual market power and the legal standard are mutually consistent with his proclamation.

But so are others, indeed, an infinite set of possible other beliefs. To illustrate the problem, let us consider just two, a higher view of actual and legally requisite market power and a lower view. 


\section{Table 4: High Beliefs about Actual Market Power in Alcoa}

\begin{tabular}{|c|c|}
\hline $\begin{array}{c}\text { Market } \\
\text { Share }\end{array}$ & $\begin{array}{c}\text { Market } \\
\text { Power }\end{array}$ \\
\hline $33 \%$ & $25 \%$ \\
\hline $60 / 64 \%$ & $50 \%$ \\
\hline $90 \%$ & $75 \%$ \\
\hline
\end{tabular}

The empirical assessments in table 4 would rationalize Hand's pronouncement if the legally requisite degree of market power was near or somewhat above $50 \%$.

\section{Table 5: Low Beliefs about Actual Market Power in Alcoa}

\begin{tabular}{|c|c|}
\hline $\begin{array}{c}\text { Market } \\
\text { Share }\end{array}$ & $\begin{array}{c}\text { Market } \\
\text { Power }\end{array}$ \\
\hline $33 \%$ & $1 \%$ \\
\hline $60 / 64 \%$ & $3 \%$ \\
\hline $90 \%$ & $10 \%$ \\
\hline
\end{tabular}

In table 5, Hand's proclamation is consistent with a market power legal threshold of, say, $3 \%$ or $4 \%$.

It is immediately apparent from tables 3-5 that the Alcoa pronouncement gives us no idea of how much market power Hand thought was associated with any market share. ${ }^{51}$ A $33 \%$ market share, for example, might be associated with a price-cost margin of $1 \%, 5 \%$, or $25 \%$, or any other figure. A $90 \%$ share with $10 \%, 30 \%, 75 \%$, or anything else. Clearly, we learn nothing about question 1 on empirical assessment.

On question 2, the legal policy judgment, Hand's statement fares no better. We can see from tables 3-5 that he may have had in mind a market power requirement for monopolization of roughly $4 \%, 17 \%$, just over $50 \%$, or any other level. Nothing is learned about this question either.

To reinforce these conclusions, consider crossing the two sets of answers. If table 3

\footnotetext{
${ }^{51}$ As an aside, this point casts a new and rather different light on decades of debate about the correctness of Hand's market definition in Alcoa. Market definition is supposed to be about assisting the process of making market power inferences. Since we have no clue what market power inference Hand implicitly made, it seems difficult (impossible) to say whether it was too high or too low. Hand could readily have understated market power by choosing the market definition with the $90 \%$ share and he might have overestimated market power if he had chosen the market definition yielding the $33 \%$ share, depending on how much market power he thought such shares implied.
} 
depicts reality, then if the legal standard was in fact $4 \%$ (à la table 5), even the $33 \%$ share would have been enough. But if the legal standard was just over 50\% (à la table 4), even the 90\% market share would not have been enough. If table 5 was reality, then even the $90 \%$ market share would have been inadequate under our originally hypothesized Alcoa legal standard of $17 \%$, and if table 4 was reality, then even the $33 \%$ market share would have been clearly sufficient under that legal standard.

In sum, we can have no idea of what Hand was saying either about actual market power or about the legal threshold. A direct implication is that, rather than being an important precedent articulating market power requirements in monopolization cases, as is widely believed, it is an entirely useless one. Any future case with any market share whatsoever could involve clearly enough market power or clearly inadequate market power under Alcoa. For example, if table 5 is correct, we might imagine that most future monopolization cases, except the highly frivolous, would readily pass the market power threshold, whereas if table 4 is correct, very few might. Even more, for any case we could construct a market share / market power table and state an associated legal threshold consistent with the table that generates whatever outcome we wish.

How can it be that Hand's statement seems so much more precise and substantial than we usually see from courts yet is entirely content free? The answer is that he conflates the two questions. To answer question 1 , he would have had to make a statement about how much market power was associated with various market shares in the case at hand. To answer question 2 , he would have had to state how much market power is required for the offense of monopolization. But his famous proclamation does neither. Instead, it mixes these two questions and employs the common denominator of market share, which we have seen is not a proper form of answer to either question.

The precedent can, in a sense, be rescued by resort to the standard reference market construct. But it is a challenging mission, one that requires identifying the standard reference market that Hand implicitly employed in making his proclamation. Two possibilities seem most plausible (although both are obviously more than a stretch, closer to fantasy). One is to impute the idea that, since he knew he was offering a precedential test, he must have intended to refer to something like the average market in making his pronouncement. ${ }^{52}$ However, as the discussion in section IV.A indicates, this interpretation is inconceivable. He would have needed empirical information on all markets, what market power is associated with varying market shares in those markets, and so forth. Surely, no such information was in the record, the parties' briefs, or in uncited academic literature that might have enabled him to take judicial notice.

\footnotetext{
${ }^{52}$ And one might have further supposed that he chose (manipulated) the market definition to match this benchmark as closely as possible. "[M]ost critics have simply assumed that Hand picked the market share percentages he needed to proceed onto the next stage of the analysis and then worked backwards, gerrymandering the market definition until it produced the desired result." Waller, supra note 1, at 131. A difficulty with viewing Hand as playing fast and loose with market definition in order to meet a legal test is that he essentially made up the test himself, and he could instead have just moved the bar accordingly (although, for the reason noted in part VI, it may have been difficult to announce a standard for monopolization that could be met by a low market share).
} 
It seems less farfetched to suppose that he was talking about the aluminum market in the place and time involved in Alcoa itself. Accordingly, we can imagine that he knew how much market power was associated with each of the market share figures, did have a market power threshold (properly denominated) in mind, but chose not to mention any of them and instead to speak in terms of the market shares. This depiction likewise seems implausible. ${ }^{53}$

Suppose, however, that this interpretation is what we impute to him. Could Alcoa then serve as a precedent on the market power requirement in monopolization cases? The answer is a highly qualified yes. The qualification is that we still need to know Hand's table; that is, we need to know the market power figures he associated with each market share to recover at least approximately the corresponding market power threshold (that is, what threshold is at or just over the market power associated with 60/64\%). Recovering this information directly would require the discovery of personal notes or a highly probative seance. Failing that, we could on our own reconstruct our best estimate of the correct market share / market power table based on the aluminum industry in the United States at that time, assume that Hand's analysis was similar to ours, and thereby impute an approximate market power requirement. That is, a necessary condition to use Hand's statement as a precedent is a detailed, historical assessment of market power in the aluminum industry as it was presented to Hand in Alcoa. ${ }^{54}$

It may seem unkind to pick on Hand and his fellow panelists in this manner. Indeed, the foregoing critique is largely applicable to all pronouncements of market share thresholds, whether by courts, agencies, or commentators. ${ }^{55}$ For example, suppose that a $50 \%$ market share is presumptively required for dominance. Using tables $3-5$ as possible tables that might be envisioned by whomever is making the statement, the implied market power requirement (interpolating and rounding) might be $2 \%, 10 \%$, or $40 \%$ - or, as we have seen, any other figure since we can imagine other tables as well. Again, to try to pin down the answer, we might impute to the promulgator a standard reference market. But what standard reference market? That is the problem. As with Hand, we might suppose that the average market was intended. But are we to suppose that anyone making various market share statements has ever undertaken such an exercise? If the market share threshold is announced in a case, even partially, as by Hand (for example, by observing a market share of 38\% and stating that, under the circumstances, it is not enough), we could do the appropriate retrospective empirical reconstruction: going back to the facts of that case to derive the best estimate of actual market power and deeming it to be sufficient or insufficient, depending on the case's outcome. Notice

\footnotetext{
${ }^{53}$ Among other reasons, if he had actually determined Alcoa's market power, it would have been one figure, and that figure would be correct regardless of which market definition he thought best.

${ }^{54}$ Consider the implications for a litigated case that seeks to apply Alcoa. One party might argue that the market share under Alcoa's test favors its bottom line. To do so, however, it would have to offer evidence and argument about market power not only in the case at hand but also in the aluminum industry before the court in Alcoa. Then, the other side might, in addition to challenging the market power claims in the present case, challenge its opponents' analysis of the historical aluminum industry, perhaps arguing that the market elasticity of demand was different so that the market shares in Alcoa convey a different degree of market power than asserted.

${ }^{55}$ The immediately preceding paragraph on the aluminum industry would apply, mutatis mutandis, to such pronouncements if they concerned a particular case, but not to an abstract pronouncement of a market share requirement. Of course, that criticism was of an attempt to make sense of such pronouncements, and, indeed, of the most plausible (however implausible) of the two possibilities, so it is hardly a virtue to be exempt from this problem.
} 
that, in such an exercise, knowing the market share figure in the case is of little help in predicting what the conclusion of such an investigation would be.

We can be pretty confident that there is no way out of this bind. As stated, such market share pronouncements state a single figure that, of necessity, relates to two qualitatively distinct questions, one empirical and one normative. It cannot hope to answer both, and in fact it illuminates neither, primarily because the statement of a market share is not of a kind with an inquiry about market power.

\section{REFLECTIONS ON OFFICIAL (NON)PRONOUNCEMENTS OF MARKET POWER REQUIREMENTS}

Section II.B notes the familiar point that market power requirements are typically denominated as market share threshold tests. The discussion of Alcoa in part V reinforces the related idea that articulation through market share tends to be exclusive, without any statement of the degree of market power thought to be associated with any market share. These market share requirements have an ipse dixit character, although it is hard to see how it could be otherwise since the underlying legal policy question concerns market power, which does not translate to market share (without use of something like the standard reference market construct, which has not been employed).

One way to reinforce the lack of market power answers to the legal market power question is to consider a case in which the magnitude of market power is not in dispute. Suppose, for example, that in a monopolization case, when the two sides' expert reports come in, they both have precisely the same quantitative bottom line, that the dominant firm can elevate price $18 \%$ above the competitive level. ${ }^{56}$ Or imagine that the parties stipulate that market power is $18 \%$. In either situation, who wins? A case like this should be the easiest imaginable; squabbles about market definition and the various factors that arguably mean that a given market share conveys more or less market power than usual are entirely moot. Such evidence on market power is just that, evidence on market power. Once both sides are in complete agreement on the factual inference to be drawn from all such information, there is no need for further proceedings. ${ }^{57}$ All that remains is the adjudicator's answer. But what is it? We have no ideanot from Alcoa, not from decisions in other cases finding this or that market share sufficient or inadequate, and not from agencies' or commentators' pronouncements of market share

\footnotetext{
${ }^{56}$ This article raises another question about expert evidence: whether U.S. courts should allow into evidence conventional expert opinions on extant market power that are couched in market shares terms. Rule 702 of the Federal Rules of Evidence, as amended in light of Daubert v. Merrell Dow Pharms., Inc., 509 U.S. 579 (1993), and subsequent cases, requires that an expert's "testimony is the product of reliable principles and methods." The problem is that market share is not an answer to the empirical market power question as a matter of principle. Of course, it would be difficult for a court both to exclude such evidence and to apply a market power test denominated in market share terms, under which such evidence seems essential.

${ }^{57}$ To a large extent, it is inapt to respond to this lacuna by stating that one might need to know more about the facts and circumstances because the ordinary reason we may need to consider additional information is to refine our inference from market share to market power, whereas in this example we have already made that inference and it is uncontested.
} 
requirements. ${ }^{58}$

How can we explain this state of affairs, with many market share standards being offered yet none really in terms of market power, which is the relevant legal policy question? It seems that courts - but not only courts; also agencies, lawyers, and commentators - are reluctant to give direct quantitative answers to either of our two questions: question 1, on how much market power exists in a given case, ${ }^{59}$ and question 2 , on how much market power should be required. ${ }^{60}$ Regarding the former, the hypothetical example is unusual not just because each side's experts happen to agree, but also because each presents a clear bottom line denominated in market power terms. $^{61}$

This quantitative queasiness does not seem to extend to market shares. Two partial explanations can be offered. The first is that, with an offense like monopolization, the term monopoly has a familiar, ordinary meaning: Monopoly denotes control by one party, suggesting a market share of $100 \%$. Not being overly literal (and perhaps also because the statute speaks of monopolization, not monopoly per se), a market share of $90 \%$ seemed to Hand, his fellow panelists, and most others as close enough. A share of $33 \%$ by contrast, feels way off the mark. Shares of $60 \%$ or $64 \%$ appear doubtful by this ordinary language standard. ${ }^{62}$ By contrast, EU Article 82 refers to a dominant position, which ordinarily conveys one that is commanding or controlling without being exclusive, as with the term monopoly, so perhaps it is unsurprising that a more moderate share, perhaps something like $50 \%$, is often thought sufficient. That is, even though market power has been defined in economic terms (see section II.A) and evidence is economic in nature, the actual standards may reflect a much more semantic, simpleminded interpretation. Moreover, since such a representation is in market share terms, the legal tests for

${ }^{58}$ See, e.g., AREEDA, KAPLOW, \& EDLIN, supra note 4, 492-93 ("Suppose we knew that a given defendant could price 25 percent above the competitive level. Is that enough? . . . You will see that the courts have emphasized power over price without indicating how much power we should be concerned about."); Kaplow \& Shapiro, supra note 4, at 1187.

${ }^{59}$ See, e.g., AREEDA, KAPLOW, \& EDLIN, supra note 4, 492 ("The starting point is the lay intuition that a firm with 100 percent of a market possesses market power. It almost surely has the power to restrict output and to charge more than the perfectly competitive firm. But how much more? Five or 500 percent? Such answers, never supplied, are essential if one is to infer market power from market share."); id. at 498-99 ("But even if such problems are overcome, the power implications of any particular market share remain obscure. The courts have not stated how much power they believe to be associated with given market shares.").

${ }^{60}$ See, e.g., id. at 499.

${ }^{61}$ Instead, ordinarily the factual material is presented and analyzed to provide an answer not about market power but instead about market definition. From there, one measures the market share and then makes further inferences about market power, most of which are qualitative. See supra note 18. This jumbling of the order and relationships among the key concepts indicates serious problems with the market definition / market share paradigm, as developed in Kaplow, supra note 3 .

${ }^{62}$ Hand's pronouncement, even if ipse dixit, does not strike readers as strange (which helps to explain why its emptiness has largely escaped notice). By contrast, suppose that Hand had declared that an elevation of price above marginal cost of $26 \%$ is enough, $14 \%$ is doubtful, and $6 \%$ is not. Presumably, the court would have found it difficult to select such numbers and would imagine that subsequent courts and commentators would be skeptical. (If the Alcoa court had first made a quantitative market power finding, on question 1, the choice of some figure for a statement on question 2 would have been natural, but there would still be the problem of defending the first, empirical assessment; moreover, explaining why, say a $26 \%$ price elevation was enough might have been far more difficult than simply asserting that a firm with a $90 \%$ market share looks like a monopolist.) 
market power employ the same language.

A second possible explanation, interconnected with the first in a mutually reinforcing manner, concerns factfinding, more focused on question 1. As suggested elsewhere, it seems easier to choose a relevant market, often selecting the best from a set of two or three leading contenders, than to make a quantitative finding on market power. ${ }^{63}$ Once that task is complete, one does have a market share (computing it is usually straightforward) but no market power figure. ${ }^{64}$ Accordingly, it seems easier to stop there, or to suggest some qualitative upward or downward adjustments. Conveniently, with a test denominated in market share, stopping short is particularly attractive. Coming from the other direction, if agencies or adjudicators were to announce quantitative market power thresholds, as seems most logical even if more difficult to explicate, then applications would require quantitative decisions, doubling the discomfort. These same considerations may also help to explain why commentators, even those critical of Alcoa in particular or of features of the law on market power more generally, have not pursued the sort of criticism advanced in this article.

In light of these considerations, the current state of affairs - in which legal thresholds are denominated in market share terms and factual inquiries likewise focus on market share - may not seem all that surprising. Nevertheless, as is apparent since section III, the practice is impossible to defend as a matter of rational economic policy since both the empirical and normative questions are about market power, not market share. Moreover, we have seen that focusing on market share ordinarily results in conflating these qualitatively distinct questions in a manner that undermines the ability to provide meaningful (substantive) guidance.

Before concluding, it is useful to consider briefly one realm that may seem exceptional, but on reflection less so than meets the eye: the hypothetical monopolist test under the U.S. Merger Guidelines (which are followed in other jurisdictions to a degree). ${ }^{65}$ These guidelines mix a quantitative market power rule - which is used only for purposes of defining the market - and market shares - which are used more directly for assessing the effects of the merger on price. In attempting to determine whether a small but significant and nontransitory increase in price (SSNIP) would be imposed by a hypothetical monopolist in a postulated product market, "[ $\mathrm{t}]$ he Agencies most often use a SSNIP of five percent of the price paid by customers for the products or services to which the merging firms contribute value." ${ }^{\prime 66}$ If the deception).

${ }^{63}$ See, e.g., Kaplow, supra note 3, at 506-08 (explaining that the view has superficial appeal but involves self-

${ }^{64}$ Given a market definition, determining the market share is often viewed as a mechanical exercise (but see supra note 40 (noting some complications)), whereas coming up with a quantitative estimate of market power is regarded to be a difficult task. As emphasized in $i d$. at 430-44, this view is quite misleading since the market definition process implicitly requires that one first do all the work necessary to formulate a quantitative market power estimate.

${ }^{65}$ See supra note 11.

${ }^{66}$ U.S. MERGER GUIDELINES, supra note 4, §4.1.2. Having speculated earlier in this part about how the current predicament of using market shares to answer market power questions came about and linking this phenomenon to a desire to avoid quantitative pronouncements, it is interesting to conjecture further on the hypothetical monopolist test and the five percent SSNIP threshold. The modern version of the U.S. Merger Guidelines had its genesis in the 1980s, when the enforcement agencies attempted to ground the merger review process more solidly in economics. Market definition was a particular soft spot, and it seems very difficult to provide any sort of solid foundation for a choice between markets 
hypothetical monopolist in the narrowest market could impose such an increase without losing profits, that product market definition sticks; if not, the market is broadened and the test is repeated, and so on until the test is satisfied. However, once the market is defined, concentration and market shares become the focus, with the post-merger HHI and the increase in the HHI determining the presumptive degree of competitive concern and resulting scrutiny. ${ }^{67}$ The HHI, in turn, is the sum of the squares of the market shares of the firms in the industry, which further implies that the increase in the HHI is twice the product of the two merging firms' market shares. ${ }^{68}$

To appreciate the significance of market shares under this hybrid approach, it is important to emphasize that the five percent threshold for defining markets is not the criterion for significant competitive effects. On one hand, much smaller effects can trigger intensive scrutiny and prohibition. (This point is in a sense obvious since the hypothetical monopolist need only be able to raise price five percent and mergers well short of merger to monopoly are covered. ${ }^{69}$ ) On the other hand, a merger could elevate price by more than percent and slip under the Merger Guidelines' radar if their approach is in fact followed. ${ }^{70}$ This substantial mismatch of actual market power effects (question 1) and the legal standard (question 2) reflects the conflation of the two questions in the Merger Guidelines' formulation as well as the use of

that is not quantitative. The hypothetical monopolist test has appeal since a market definition might be thought independent of the particular setting (merger, monopolization; low concentrations or high); five percent seems to be as good an arbitrary figure as any; and the use of HHIs had some appeal because then-existing tests were all in terms of concentration ratios and market shares (not market power) and the HHI seemed to have better economic grounding than other concentration measures in some respects (and also had more of a technical feel). By contrast, announcing market power thresholds would have seemed radical: out of sync with prevailing law and thus less likely to be adopted by courts and more likely to elicit a hostile reaction from traditionally minded practitioners and the legislature.

${ }^{67}$ See id., §5.3. For a criticism of the focus on HHIs rather than on price elevation, see, for example, Jerry A. Hausman \& J. Gregory Sidak, Evaluating Market Power Using Competitive Benchmark Prices Instead of the HerfindahlHirschman Index, 74 ANTITRUST L.J. 387 (2007).

${ }^{68}$ These calculations use pre-merger market shares, abstracting from how they would adjust in the post-merger equilibrium. To illustrate the index, if there are ten firms each with a $10 \%$ share, the HHI is 1000 (ten times $10^{2}$ ). A merger of two firms would increase the index by 200 (two times 10 times 10) to 1200 - which can be verified by summing eight times $10^{2}(800)$ and one times $20^{2}(400)$. To illustrate the application of the guidelines more concretely, consider the upper range, and in particular the rule: "Mergers resulting in highly concentrates markets [i.e., with an HHI above 2500] that involve an increase in the HHI of more than 200 points will be presumed to be likely to enhance market power." U.S. MERGER GuIDELINES, supra note 4, §5.3. Note that four equal-sized firms implies an HHI of 2500; five, 2000. Regarding an increase of 200, this increment would arise, say, from a merger of two $10 \%$ firms, as in the above example.

${ }^{69}$ See the illustration in the preceding note about how much of an increase in the HHI is required to be in the zone of highest danger under the guidelines. More broadly, see Kaplow, supra note 3, at 487-88 n.99, and Louis Kaplow, Market Definition and the Merger Guidelines, REV. INDUS. ORG. (forthcoming 2011), discussing how the Merger Guidelines' amalgam of price elevation and market definition / market share analysis, despite its scientific air, in fact achieves determinacy at the expense of coherence.

${ }^{70}$ In defining the market, the Merger Guidelines' approach begins with the narrow, homogeneous goods market. But if there is a very low elasticity of demand and supply in that market, the hypothetical monopolist's market power could be tremendous. A merger in a rather unconcentrated market (post-merger HHI under 1000) could enable price increases of more than $5 \%$ through the unilateral exercise of market power. For example, under Cournot competition, the industry-wide, output-weighted price-cost margin equals the HHI divided by the elasticity of market demand. See, e.g., Kaplow \& Shapiro, supra note 4, at 1085. Therefore, any increase in the HHI would suffice as long as that elasticity is sufficiently small. (For a more rigorous analysis of mergers under Cournot competition, see Joseph Farrell \& Carl Shapiro, Horizontal Mergers: An Equilibrium Analysis, 80 AM. ECON. REV. 107 (1990).) 
market shares (to a significant extent) for both questions. Moreover, these core problems have been largely ignored despite the existence of substantial legal and economic analysis of the Guidelines, the many revision cycles over the past three decades, ${ }^{71}$ and the imitation of the Guidelines by other jurisdictions, generating parallel sets of commentary.

\section{CONCLUSION}

We have seen that there are two distinct questions, one involving an empirical assessment (how much market power is present in a given case) and the other a legal policy judgment (how much market power should be required under the pertinent substantive rule). Both questions involve market power, yet both are ordinarily answered in terms of market shares. Market shares, however, are not even in comparable units; it is a category mistake to think that they answer either question correctly. It is demonstrated that there does exist a solution of sorts involving the construct of a standard reference market. On one hand, it works in the narrow, literal sense: It enables determinate translations between market share and market power. On the other hand, the way it works is by using entirely hypothetical market share figures in place of actual ones. In other words, the errors resulting from use of market share instead of market power are avoided, in the end, by simply addressing market power directly (both how much exists and how much should be required), cutting out the middleman, so to speak. ${ }^{72}$

Moreover, the use of the market share metric has led analysts, agencies, and adjudicators to conflate these two questions, with significant misdirection as the result. Legal threshold tests are typically stated as answers the question: "How much market share is enough?" Most famous is Hand's Alcoa pronouncement, but the problems identified in this article pertain to all market share threshold tests - and they are indeed the norm, as section II.B indicates. Such tests, it was seen, answer neither of the two pertinent questions and thus provide, on reflection, no real basis for deciding cases. Their simplicity is deceptive; their ultimate appeal seems to lie more in obscuring the real questions than in illuminating them. The obscuring effect of market share tests may help to explain why their core inaptness has not been the subject of much critical commentary.

In conclusion, therefore, it seems that the only approach, however revolutionary it may seem by comparison to current practice, is to answer each of the two key questions directly. Since both ask about market power, both need to be answered by reference to market power. Therefore, there is no avoiding the formulation of a best estimate of effects on price when answering the empirical question of how much market power exists in a particular situation.

\footnotetext{
${ }^{71}$ This characterization largely encompasses the present revision cycle, judging from the questions proposed for commentary and the comments submitted. Links can be found at http://www.ftc.gov/bc/workshops/hmg/index.shtml.

${ }^{72}$ To remind, for empirical assessment, market share can be relevant, but as one factor bearing on market power, not as a substitute for what one is trying to determine in the first place. For purposes of this article, it is irrelevant how and how often market share should play an important role in market power measurement. See also Kaplow, supra note 3 , at 447-59 (arguing that market shares can be useful in assessing a dominant firm's market power, but only when analysis focuses on the homogeneous goods market rather than on broader, redefined markets - an implication of which is that the market power associated with a given share will vary even more widely than discussed in section III.A).
} 
After all, the definition of market power is the effect on price. Likewise, in determining what degree of market power should be required as a matter of legal policy, a coherent judgment will reflect the adverse effects of augmenting market power and the various possible benefits of the practice in question. Any market power test needs to indicate how much market power (not how much of something else) is required.

This article does not assert that either of these two tasks-empirical assessment or legal policy judgment-is easy. In fact, both are quite challenging. But these difficulties are no justification for answering the wrong questions or attempting to answer the right questions in terms that are nonresponsive. It is difficult to guess the extent to which existing competition regimes have misfired - sometimes condemning benign or desirable practices or wasting resources when market power is lower than should be required, and other times exonerating malicious practices when market power is above the appropriate threshold. Of course, this murkiness is inevitable when the relevant inquiries are rarely made. 